\title{
УДК 811.111'276.3-055.1+055.2
}

Романюк Олександра - кандидат педагогічних наук, доцент, доцент кафедри англійської мови № 2, Національний університет "Одеська морська академія», вул. Дідріхсона, 8, Одеса, 65029, Україна (oleksandraromaniuk@onma.edu.ua)

ORCID: https://orcid.org/0000-0003-0484-9653;

Scopus Author ID: 57213185731

Researcher ID: AAW-5029-2021

DOI: https://doi.org/10.24919/2522-4565.2021.46.13

Бібліографічний опис статті: Романюк, О. (2021). Суб'єктне позиціонування домінуванняпідкорення під час романтичного знайомства (гендерний аспект). Проблеми гуманітарних наук: збірник наукових пращь Дрогобиџького державного педагогічного університету імені Івана Франка. Серія «Філологія», 46, 104-110. doi: https://doi.org/10.24919/2522-4565.2021.46.13.

\section{СУБ'ЄКТНЕ ПОЗИЦІОНУВАННЯ ДОМІНУВАННЯ-ПІДКОРЕННЯ ПІД ЧАС РОМАНТИЧНОГО ЗНАЙОМСТВА (ГЕНДЕРНЙ̆ АСПЕКТ)}

Анотація. Суб'єктне позиціонування домінування-підкорення є одним із найбільш фундаментальних вимірів міжособистісних стосунків романтичної діади. Порівняльний аналіз демонструє нові уявлення щцодо вербальних і невербальних засобів комунікації, які сигналізують міжособистісне домінування-підкорення під час романтичного знайомства в рамках американської лінгвокультури, а також яким частинам тіла надають перевагу різностатеві гетеросексуальні незнайомиі. Вибірка дослідження становить 40 репрезентативних кодів комунікативної поведінки, до яких увійшли 133 зразки вербальних і 1996 зразків невербальних засобів комунікащії, інічійованих американськими жінками, а також 116 зразків вербальних і 1087 зразків невербальних засобів комунікачії, ініційованих американськими чоловіками. 3 а результатами дослідження встановлено, щсо розподіл ролей під час первинної романтичної інтеракиії слідує традиційним тендерним стереотипам, згідно з якими чоловіки обирають «маскулінну» позичію домінування, а жінки - «фемінну» позииію підкорення. Вербальну дистинктивність суб 'єктного позиціонування домінування-підкорення спостережено в рольовому дейксисі адресанта й адресата. У фемінному романтичному медіадискурсі превалює комунікативна установка на адресанта й адресата; у маскулінному романтичному медіадискурсі надано пріоритет комунікативній установиі на адресанта. Невербальну дистинктивність суб'єктного позииіонування домінування-підкорення спостережено в превалюванні невербального вираження домінування в маскулінному романтичному медіадискурсі; натомість надання преференцій невербальному вираженню підкорення простежено у фемінному романтичному дискурсі. Гендерна паритетність виявляє себе у використанні однакових частин тіла для сигналювання позииії домінування, а дистинктивність частин тіла - для вираження позичії підкорення.

Ключові слова: домінування, підкорення, тендерні ролі, романтичний медіадискурс, первинна романтична інтеракція, вербальні засоби комунікації, невербальні засоби комунікації.

ROMANIUK Oleksandra - Doctor of Philosophy, Associate Professor, Associate Professor at the English Language Department No. 2, National University "Odesa Maritime Academy”, 8, Didrikhson str., Odesa,65029,Ukraine (oleksandraromaniuk@onma.edu.ua)

ORCID: https://orcid.org/0000-0003-0484-9653

Scopus Author ID: 57213185731

Researcher ID: AAW-5029-2021

DOI: https://doi.org/10.24919/2522-4565.2021.46.13 
To cite this article: Romaniuk, O. (2021). Sub'iektne pozytsionuvannia dominuvannia-pidkorennia pid chas romantychnoho znaiomstva (gendernyi aspekt) [Relational dimensions of dominance-submission in romantic encounters (gender aspect)]. Problemy humanitarnych nauk: zbirnyk naukovych prats Drohobytskoho derzhavnoho pedahohichnoho universytetu imeni Ivana Franka. Seriia «Filolohiia»-Problems of Humanities. "Philology" Series: a collection of scientific articles of the Drohobych Ivan Franko State Pedagogical University, 46, 104-110. doi: https://doi.org/10.24919/2522-4565.2021.46.13 [in Ukrainian].

\section{RELATIONAL DIMENSIONS OF DOMINANCE-SUBMISSION IN ROMANTIC ENCOUNTERS (GENDER ASPECT)}

Summary. Dominance-submission is one of the most fundamental dimensions of the interpersonal relationship of a romantic dyad. The comparative analysis demonstrates new insights into verbal and nonverbal behaviours, which signal interpersonal dominance-submission within romantic encounters in American dating culture, as well as which parts of the body are preferred to initiate face-to-face romantic interactions by heterosexual strangers. The sample of the study consisted of 40 representative codes, which included 133 verbal and 1996 nonverbal immediacy cues initiated by American women, as well as 116 verbal and 1087 nonverbal immediacy cues initiated by American men. The findings showed that the distribution of the roles during the initial romantic interactions follows the traditional gender stereotypes. Accordingly, men choose the "masculine" position of dominance, while women prefer the "feminine" position of submission. First, the verbal distinctiveness of dominance-submission is observed in the role deixis of the speaker and the addressee. The results suggest that within interactional control in the task performance cues, both self-nomination and identification of the addressee prevail in the feminine romantic media discourse; while, self-nomination is significantly preferred in the masculine romantic media discourse. Second, the nonverbal distinctiveness of dominance-submission is observed in the prevalence of nonverbal expression of the dominance in the masculine romantic media discourse; conversely, the preference for the nonverbal expression of submission is found in the feminine romantic discourse. Ultimately, gender equality is manifested in signalling dominance by the identical body parts, while the distinctiveness of the body parts is observed in expressing submission.

Key words: dominance, submission, gender roles, romantic media discourse, initial romantic interaction, verbal immediacy cues, nonverbal immediacy cues.

Постановка проблеми. Міжособистісні стосунки імпліцитно або експліцитно детерміновані відповідно до ступеня домінування, підкорення чи паритетності, що існує всередині змішаної діади (Burgoon, Johnson, Koch, 1998). На відміну від влади та соціального статусу комунікантів, які можуть бути латентними, суб'єктне позиціонування домінування-підкорення маніфестують упродовж усього континууму міжособистісної інтеракції з внутрішньо властивими комунікативній ситуації суб'єктивними й об'єктивними інтегративними дескрипторами (Морозова, 2011; Ущина, 2016; Dunbar \& Burgoon, 2005; Gifford, 1991).

Глобальне переосмислення соціальної ролі чоловіка та жінки детермінує доцільність наукового аналізу зумовлених гендерною належністю комунікантів дистинктивних рис їхньої комунікативної поведінки під час романтичного знайомства, який полягає у встановленні характеру міжособистісної взаємодії: від гендерної асиметрії шляхом суб'єктного позиціонування домінування-підкорення до гендерної паритетності.

Аналіз останніх досліджень і публікацій. Домінування-підкорення $\epsilon$ одним із найбільш фундаментальних і широко визнаних вимірів міжособистісних стосунків діади, виражених за допомогою вербальної й невербальної поведінки (Argyle, 1988; Burgoon, Hale 1984; Massey-Abernathy, Haseltine, 2019). Так, опущені брови, обличчя без усмішки (Witkower, Tracy, Cheng, Henrich, 2020), експресивність у рухах тіла й голови, більш експансивні та вертикальні пози, мімічна виразність, ініціація інтеракції, указівка на себе, більший за тривалістю й частотністю комунікативний обмін, переривання співрозмовника (Burgoon, Wang, Chen, Pentland, \& Dunbar, 2021) корелюють із позицією домінування. Натомість уникнення прямого зорового контакту, розм'якле тіло (Weeks, Heimberg, Heuer, 2011), кволі рухи голови й обличчя, коротший за тривалістю і 
нижчий за частотністю комунікативний обмін (Burgoon, Wang, Chen, Pentland, Dunbar, 2021) $\epsilon$ ознаками позиції підкорення.

Суб'єктне позиціонування домінування-підкорення також диференціюють відповідно до контексту комунікативної події. Ба більше, учені зазначають, що розподіл ролей під час діадичної інтеракції слідує традиційним гендерним стереотипам, згідно 3 якими чоловіки обирають «маскулінну» позицію домінування, а жінки - «фемінну» позицію підкорення (Cameron, Curry, 2020). Проте питання щодо того, які саме засоби комунікації сигналізують міжособистісне домінування-підкорення під час первинної романтичної інтеракції, а також яким частинам тіла надають перевагу різностатеві гетеросексуальні незнайомці, досі не вивчені. Дослідження $\epsilon$ певним внеском в усунення цієї прогалини 3 огляду на теоретичні передумови суб'єктного позиціонування домінування-підкорення під час романтичного знайомства, що засвідчуе його актуальність.

Метою статті $\epsilon$ встановити вербальне й невербальне вираження позицій домінування та підкорення незнайомців під час первинної романтичної інтеракції.

Для досягнення мети потрібно вирішити такі завдання: виділити й описати вербальне та невербальне вираження міжособистісного домінування-підкорення, ініційоване жінками і чоловіками під час первинної романтичної інтеракції; установити співвідношення різних частин тіла з метою виразити позицію домінування й підкорення, а також виявити гендерні преференції щодо їх уживання.

Аналіз проведено на матеріалі міжособистісних романтичних інтеракцій медіаперсонажів Американського реаліті дейтинг-шоу "The Bachelor" i "The Bachelorette", які слугують інформаційним путівником для з'ясування соціальних і лінгвокультурних норм, а також інструментом вивчення романтичних стосунків, представлених, зокрема, медіаджерелами (Романюк, 2018; Ступак, 2017; Kitzinger, 2001; Rose, Frieze, 1989). Отже, вербальна й невербальна поведінка медіаперсонажів у рамках романтичного медіадискурсу позитивно корелює з дотриманням гендерних стереотипних установок змішаної романтичної діади, традиційними уявленнями щодо ініціації романтичних стосунків, іманентними американській лінгвокультурі, а також може слугувати передбачуваними романтичними сценаріями «Створення першого враження» для багатомільйонної аудиторії медіаспоживачів у реальному житті.

Виклад матеріалу. Вербальне вираження міжособистісного домінування-підкорення реалізується шляхом комунікативних установок адресантів з ідентифікацією учасниць/учасників комунікативного акту, тобто рольовий дейксис адресанта й адресата, представлений у рамках ініціації одного коду фемінного та маскулінного комунікативного ходу продовження стосунків. Первинній романтичній інтеракції властиві такі напрями комунікативної установки:

1) на адресанта, який визнає себе виконавцем центральної ролі в міжособистісній інтеракції й, обираючи позицію домінування, покладає на себе відповідальність. Комунікативну установку реалізують за допомогою вербальних засобів дейктичної сфери займенника першої особи однини, наприклад: "So, (I) look forward to getting to know you better" (Bryan, "The Bachelorette", S13E01, 2017).

2) на адресата, якому відведено центральну роль у міжособистісній інтеракції, надано позицію домінування, адже відповідальність покладено саме на нього. Комунікативну установку реалізують за допомогою вербальних засобів дейктичної сфери займенника другої особи однини, наприклад: “I'm joking! I know nothing about wine except that I like to drink it. But maybe you can teach me" (Shira, "The Bachelor", S16E01, 2012).

3) на обох учасників комунікачії (інклюзивно), тобто демонстрація співрозмовникові включеності адресанта в особисту сферу адресата. Комунікативну установку реалізують за допомогою інклюзивних особових $\mathrm{i}$ присвійних займенників, які створюють комунікативний образ адресата й адресанта як єдиного цілого та допомагають адресантові налаштувати адресата на продовження стосунків після романтичного знайомства, наприклад: "We're gonna have so much fun tonight" (Elyse, “The Bachelor”, S16E01, 2012).

У поодиноких фрагментах засвідчені водночас три напрями комунікативної установки, наприклад: “Unfortunately, I get to go 
now. Why don't I give you my number and you call me and then we will hang out soon" (Mike, "The Bachelorette", S10E01, 2014). Так, медіаперсонаж спочатку визнає себе виконавцем центральної ролі "Why don't I give you my number”, далі доручає центральну роль адресатові "you call mе" й завершує інклюзивністю комунікативної установки "we will hang out soon".

Невербальному вираженню міжособистісного домінування-підкорення теж властиві дистинктивні риси, зумовлені гендерною належністю комунікантів. Наприклад, жінки комунікують свій романтичний інтерес через невербальні засоби самопрезентації та підкорення, як-от: відкидання волосся, уникнення прямого зорового контакту, рухи плечима, нахил голови убік, тоді як чоловіки роблять те саме через орієнтацію тіла й невербальні засоби домінування, а саме: нахил тулуба вперед до жінки, сплетення рук за шиєю, рука на зап'ясті або долоні другої руки, прямий зоровий контакт тощо (Grammer, 1990).

Установлено, що під час романтичного знайомства суб'єктне позиціонування домінування-підкорення виражене шляхом ініціації 39 кодів невербальних засобів комунікації (далі - НЗК). Так, домінантну роль партнера виражено ініціацією 25 кодів НЗК, а готовність до підкорення - ініціацією 14 кодів НЗК. Незважаючи на те що за медіаформатом реаліті дейтинг-шоу ініціатором романтичної інтеракції є учасниця або учасник, розподіл ролей умотивовано гендерною належністю медіаперсонажів (див. рис. 1).
Відповідно до наведених даних, чоловікам більш властива домінантна позиція (пор., $67,6 \%$ vs. 77,5\%), тоді як жінки, навіть ініціюючи романтичну інтеракцію, частіше сигналізують покірність, невпевненість у собі та збентеження (пор., 32,4\% vs. 22,5\%).

Суб'єктне позиціонування домінування-підкорення може бути виражене різними частинами тіла, які сигналять комунікативні інтенції романтичної діади як нарізно, так і в сукупності. Зокрема, установлено, що жіночу покірність демонструють зазвичай делікатні жести, тоді як домінантну позицію - більш асертивні або експансивні (Richards, Rollerson, \& Phillips, 1991).

Отримані результати продемонстрували, що 25 кодів невербальної поведінки домінування реалізовано такими частинами тіла: 3 НЗК ініційовано головою: кивання головою, заперечення головою, відкидання волосся назад; 3 НЗК ініиійовано очима: взаємний погляд, підняття брів, підморгування; 3 HЗК інічійовано обличчям: щастя, здивування, поцілунок у щоку; 1 HЗК інічійовано плечима: погойдування плечами з боку в бік; $13 \mathrm{H3K}$ ініційовано руками: інтимні обійми, тримання за руки, гра 3 волоссям, інтимні обійми 3 поплескуванням по спині, указування на себе/ партнера/убік, рукостискання, руки на стегнах, махання рукою, рахування на пальцях, запрошення на танець, поцілунок руки; 2 HЗК ініиійовано тулубом: вертикальна постава, нахил тулуба назад.

14 кодів невербальної поведінки підкорення реалізовано такими частинами тіла:

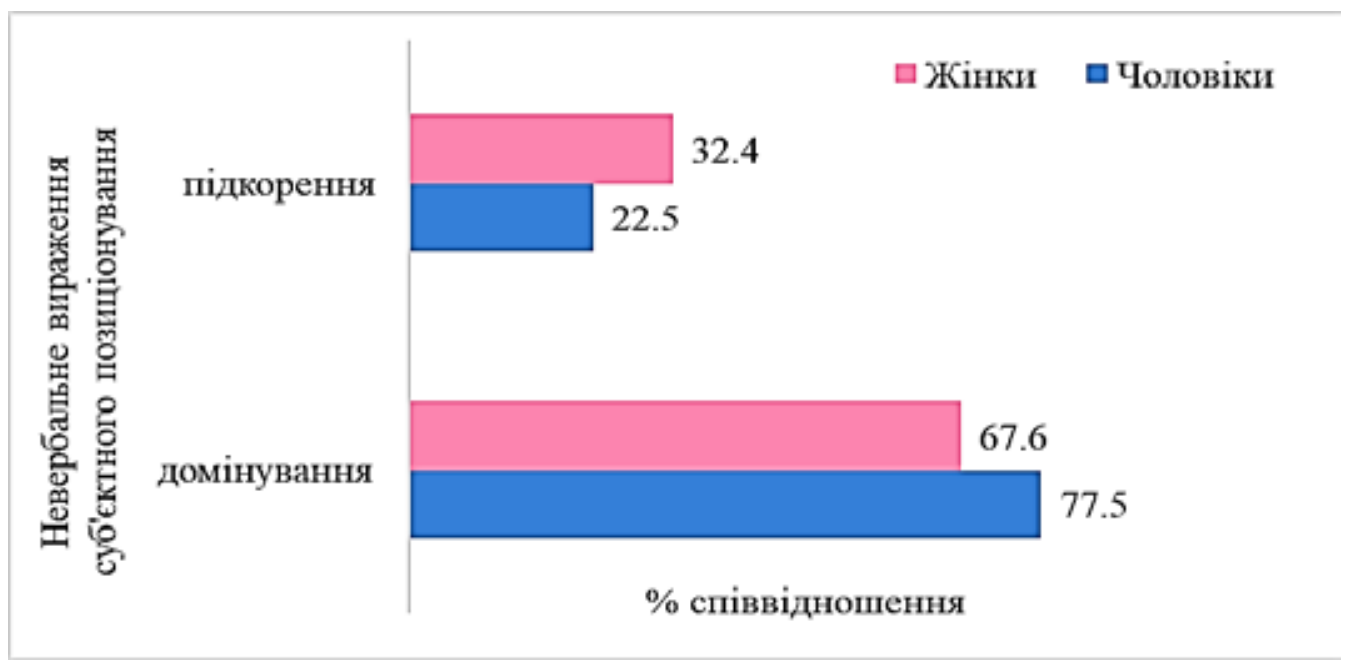

Рис. 1. Невербальне вираження домінування-підкорення 
1 НЗК ініційований головою: нахил голови; 4 НЗК ініиійовано очима: погляд униз, убік, угору, взаємний погляд з-під брів; 1 HЗК ініuійовано обличчям: покусування нижньої губи; 1 НЗК інічійовано плечима: знизування плечима; 5 НЗК інічійовано руками: розправляння одягу, долоні назовні, руки спереду, складання рук (молитва), закриття руками обличчя; 2 НЗК інічійовано тулубом: нахил тулуба вперед, гойдання тулуба з боку в бік.

Порівняльний аналіз фемінної й маскулінної невербальної поведінки встановив співвідношення різних частин тіла $з$ метою виразити позицію домінування та підкорення (див. рис. 2).

Представлені на рисунку 2 дані свідчать, що жінки й чоловіки використовують однакові частини тіла 3 метою невербально виразити позицію домінування під час первинної романтичної інтеракції: 1) рухами рук (пор., 34,5\% і 27,1\%); 2) поглядом (пор., $18 \%$ i $19,1 \%$ ); 3 ) рухами тулуба (пор., $17 \%$ i $20,2 \%)$; 4) виразами обличчя (пор., $16,6 \%$ i $19,8 \%$ ); 5) рухами голови (пор., $12,8 \%$ i 13,8\%) i 6) рухами плечима (поодинокі випадки, ініційовані лише жінками, 1,1\%).

Порівняльний аналіз співвідношення різних частин тіла з метою виразити позицію підкорення встановив, що жінки невербально сигналізують підкорення: 1$)$ поглядом $(34,2 \%)$; 2) рухами рук $(26 \%)$; 3) нахилом голови $(16,7 \%) ; 4)$ рухами тулуба $(13,1 \%) ; 5)$ рухами плечима (8\%) і 6) покусуванням нижньої губи
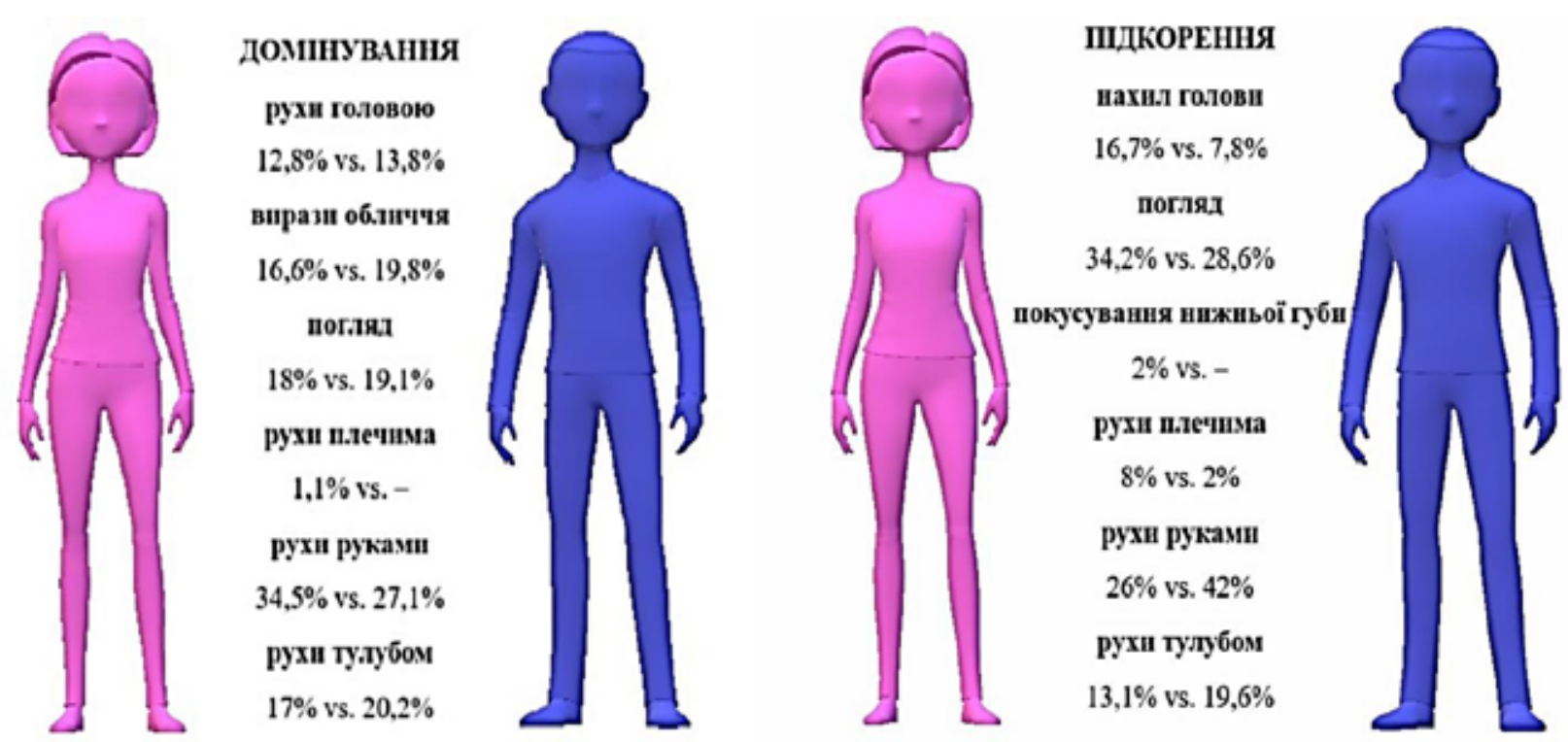

Рис. 2. Невербальне вираження домінування-підкорення частинами тіла 
курсі; натомість надання преференцій невербальному вираженню підкорення виявлено у фемінному романтичному дискурсі;

4) гендерна паритетність проявляється у використанні однакових частин тіла з метою невербально виразити позицію домінування; водночас установлено, що жінки й чоловіки надають пріоритет різним частинам тіла з метою невербально продемонструвати позицію підкорення під час первинної романтичної інтеракції. Отримані результати значно розширюють наявні дослідження щодо суб'єктного позиціонування домінування-підкорення під час міжособистісної інтеракції, окреслюючи вербальне й невербальне вираження характеру взаємодії незнайомців, іманентних американській лінгвокультурі, мотивованих сучасним контекстом флірту, залицянь і спокушання в рамках комунікативної події «Романтичне знайомство».

Перспективу подальших досліджень убачаємо в аналізі суб'єктного позиціонування домінування-підкорення, властивого іншим лінгвокультурам.

\section{ЛІТЕРАТУРА}

Морозова O.I. Stance: позиція суб'єкта дискурсивної діяльності. Вісник Київського національного лінгвістичного університету. Серія «Філологія». 2011. Т. 14. № 1. С. 87-93.

Романюк О.С. Концептуальні основи структуризації розвитку взаємовідносин романтичної діади. Bicник Житомирського державного університету імені Івана Франка. Серія «Філологічні науки». 2018. Вип. 1 (87). С. 128-132.

Ступак I.В. Особливості реалізації фреймової моделі анкет учасників дейтинг-шоу в німецькій та українській лінгвокультурах. Науковий вісник Міжнародного гуманітарного університету. 2017. № 26. С. 164-167.

Ущина В. Афективне позиціонування суб'єкта дискурсивної діяльності в англомовній комунікативній ситуації ризику. East European Journal of Psycholinguistics. 2016. Vol. 3. № 1. P. 131-139. URL: https://doi.org/10.5281/zenodo.60198 (дата звернення: 08.12.2020).

Argyle M. Bodily communication. Madison : International Universities Press, 1988. 384 p. URL: https:// doi.org/10.4324/9780203753835 (дата звернення: 08.12.2020).

Burgoon J.K., Hale J.L. The fundamental topoi of relational communication. Communication Monographs. 1984. Vol. 51. P. 193-214. URL: https://doi.org/10.1080/03637758409390195 (дата звернення: 08.12.2020).

Burgoon J.K., Johnson M.L., Koch P.T. The nature and measurement of interpersonal dominance. Communication Monographs. 1998. Vol. 65. P. 309-335. URL: https://doi.org/10.1080/ 03637759809376456 (дата звернення: 08.12.2020).

Nonverbal Behaviors "Speak" Relational Messages of Dominance, Trust, and Composure / J.K. Burgoon, X. Wang, X. Chen, S.J. Pentland, N.E. Dunbar. Frontiers in Psychology. 2021. Vol. 12. P. 1-17. URL: https://doi.org/10.3389/fpsyg.2021.624177 (дата звернення: 08.12.2020).

Cameron J.J., Curry E. Gender roles and date context in hypothetical scripts for a woman and a man on a first date in the twenty-first century. Sex Roles. 2020. Vol. 82. P. 345-362. URL: https://doi.org/10.1007/ s11199-019-01056-6 (дата звернення: 08.12.2020).

Dunbar N.E., Burgoon J.K. Measuring nonverbal dominance. The sourcebook of nonverbal measures: Going beyond words / ed. by V. Manusov. Lawrence Erlbaum Associates Publishers, 2005. P. 361-374.

Frith H., Kitzinger C. Reformulating sexual script theory. Theory Psychology. 2001. Vol. 11. №. 2. P. 209-232. URL: https://doi.org/10.1177/0959354301112004 (дата звернення: 08.12.2020).

Gifford R. Mapping non-verbal behavior on the interpersonal circle. Journal of Personality and Social Psychology. 1991. Vol. 61. P. 279-288.

Grammer K. Strangers meet: Laughter and nonverbal signs of interest in opposite-sex encounters. Journal of Nonverbal Behavior. 1990. Vol. 14, №. 4. P. 209-236. URL: https://doi.org/10.1007/BF00989317 (дата звернення: 08.12.2020).

Massey-Abernathy A.R., Haseltine E. Power Talk: Communication Styles, Vocalization Rates and Dominance. Journal of Psycholinguistic Research. 2019. Vol. 48. P. 107-116. URL: https:// doi.org/10.1007/s10936-018-9592-5 (дата звернення: 08.12.2020).

Richards L., Rollerson B., Phillips J. Perceptions of submissiveness: Implications for victimization. The Journal of Psychology: Interdisciplinary and Applied. 1991. Vol. 125. № 4. P. 407-411. URL: https:// doi.org/10.1080/00223980.1991.10543302 (дата звернення: 08.12.2020).

Rose S., Frieze I.H. Young singles scripts for a first date. Gender Society. 1989. Vol. 3. № 2. P. 258-268. URL: https://doi.org/10.1177/089124389003002006 (дата звернення: 08.12.2020). 
The Bachelor (Seasons 16-23) / The Bachelorette US (Seasons 8-15). 2012-2019. Episodes 01. URL: https:// abc.com/shows/the-bachelor/season16...23/ (дата звернення: 08.12.2020).

Weeks J.W., Heimberg R.G., Heuer R. Exploring the role of behavioral submissiveness in social anxiety. Journal of Social and Clinical Psychology. 2011. Vol. 30. № 3. P. 217-249. URL: https:// doi.org/10.1521/jscp.2011.30.3.217 (дата звернення: 08.12.2020).

Two signals of social rank: Prestige and dominance are associated with distinct nonverbal displays / Z. Witkower, J.L. Tracy, J.T. Cheng, J. Henrich. Journal of personality and social psychology. 2020. Vol. 118. № 1. P. 89-120. URL: https://doi.org/10.1037/pspi0000181 (дата звернення: 08.12.2020).

\section{REFERENCES}

Morozova, O. I. (2011). Stance: pozytsiia subiekta dyskursyvnoi diialnosti [Stance: the position of the subject of discursive activity]. Visnyk Kyyivs'koho natsionalnoho linhvistychnoho universytetu. Seriya Filologiya - Messenger of Kyiv National Linguistic University. Series Philology, 1, (Vol. 14), (pp. 87-93) [in Ukrainian].

Romaniuk, O. S. (2018). Kontseptualni osnovy strukturyzatsii rozvytku vzaiemovidnosyn romantychnoi diady [Conceptual Basis of the Romantic Relationship Development]. Visnyk Zhytomyrs'koho derzhavnoho universytetu imeni Ivana Franka. Filolohichni nauky - Zhytomyr Ivan Franko State University Journal: scientific journal. Philological Sciences (Issue 1(87), (pp. 128-132) [in Ukrainian].

Stupak, I. V. (2017). Osoblyvosti realizatsii freimovoi modeli anket uchasnykiv deitynh-shou v nimetskii ta ukrainskii linhvokulturakh [Frame model features of participants questionnaires within the dating shows in German and Ukrainian linguistic cultures]. Naukoviy visnyk Mizhnarodnoho humanitarnoho universytetu - Scientific Bulletin of the International Humanities University, 26, 164-167 [in Ukrainian].

Ushchyna, V. (2016). Afektyvne pozytsionuvannia subiekta dyskursyvnoi diialnosti v anhlomovnii komunikatyvnii sytuatsii ryzyku [Affective Stancetaking in the English Communicative Situation of Risk]. Skhidnoievropeis'kiy zhurnal psykholinhvystky - East European Journal of Psycholinguistics, 1 (Vol. 3), (pp. 131-139) [in Ukrainian].

Argyle, M. (1988). Bodily communication. Madison : International Universities Press [in English].

Burgoon, J. K., Hale, J. L. (1984). The fundamental topoi of relational communication. Communication Monographs (Vol. 51), (pp. 193-214) [in English].

Burgoon, J. K., Johnson, M. L., Koch, P. T. (1998). The nature and measurement of interpersonal dominance. Communication Monographs (Vol. 65), (pp. 309-335) [in English].

Burgoon, J. K., Wang, X., Chen, X., Pentland, S. J., Dunbar, N. E. (2021). Nonverbal Behaviors "Speak" Relational Messages of Dominance, Trust, and Composure. Frontiers in Psychology (Vol. 12), (pp. 1-17) [in English].

Cameron, J. J., Curry, E. (2020). Gender roles and date context in hypothetical scripts for a woman and a man on a first date in the twenty-first century. Sex Roles (Vol. 82), (pp. 345-362) [in English].

Dunbar, N. E., Burgoon, J. K. (2005). Measuring nonverbal dominance. In V. Manusov (Ed.), The sourcebook of nonverbal measures: Going beyond words (pp. 361-374). Lawrence Erlbaum Associates Publishers [in English].

Frith, H., Kitzinger, C. (2001). Reformulating sexual script theory. Theory Psychology, 2 (Vol. 3), (pp. 209-232) [in English].

Gifford, R. (1991). Mapping non-verbal behavior on the interpersonal circle. Journal of Personality and Social Psychology (Vol. 61), (pp. 279-288) [in English].

Grammer, K. (1990). Strangers meet: Laughter and nonverbal signs of interest in opposite-sex encounters. Journal of Nonverbal Behavior, 4 (Vol. 14), (pp. 209-236) [in English].

Massey-Abernathy, A. R., Haseltine, E. (2019). Power Talk: Communication Styles, Vocalization Rates and Dominance. Journal of Psycholinguistic Research (Vol. 48) (pp. 107-116) [in English].

Richards, L., Rollerson, B., Phillips, J. (1991). Perceptions of submissiveness: Implications for victimization. The Journal of Psychology : Interdisciplinary and Applied, 4 (Vol. 125), (pp. 407-411) [in English].

Rose, S., Frieze, I. H. (1989). Young singles scripts for a first date. Gender Society, 2 (Vol. 3) (pp. 258-268) [in English].

The Bachelor (Seasons 16-23) / The Bachelorette US (Seasons 8-15) 2012-2019. Episodes 01. Retrieved December 8, 2020 from https://abc.com/shows/the-bachelor/season16...23/.

Weeks, J. W., Heimberg, R. G., Heuer R. (2011). Exploring the role of behavioral submissiveness in social anxiety. Journal of Social and Clinical Psychology, 3 (Vol. 30) (pp. 217-249) [in English].

Witkower, Z., Tracy, J. L., Cheng, J. T., Henrich, J. (2020). Two signals of social rank: Prestige and dominance are associated with distinct nonverbal displays. Journal of personality and social psychology, 1 (Vol. 118), (pp. 89-120) [in English]. 